\title{
Problem of water supply in the Ostra and Zawadka catchements in Dębica area (Poland)
}

\author{
Anna Andrychowicz, Krystian Kawa \\ AGH University of Science and Technology, Faculty of Geology, Geophysics and Environmental Protection; \\ al. Mickiewicza 30,30-059 Krakow, Poland; e-mail: aandrych@agh.edu.pl
}

(C) 2015 Authors. This is an open access publication, which can be used, distributed and reproduced in any medium according to the Creative Commons CC-BY 4.0 License requiring that the original work has been properly cited.

Constantly growing demand of water makes it necessary to search for new perspective areas in terms of gain groundwater. Dębica area is located on the border of two geological units: the Outer Carpathians and the Carpathian Foredeep. Currently, that area suffers from water deficiency, which would have been earmarked for utility purposes. To understand this problem quantitative and qualitative assessment of the groundwater status in two catchements on this area was made.

Research in the catchments of Ostra and Zawadka was made on September 2013. For the purpose of estimating the size of quantitative resource of Zawadka and Ostra catchments the method based on information of the recharging infiltration rate was used (Nescieruk et al. 1992, Korzec \& Dendys 2014, Mars 2014). Calculation of flow rate was based on measurements of floating object method and volumetric method (Bajkiewicz-Grabowska \& Magnuszewski 2002). Furthermore, the depth of the groundwater table was estimated based on measurements performed on the wells located in that area. For qualitative status assessment samples were taken for physicochemical analysis, which was made by accredited hydrogeochemical laboratory KHiGI AGH UST (Stefańska 2014). Bacteriological analysis was carried out in the sanitary-epidemiological station in Jasło.

The results were used to perform water table map, define disposable resources $\left(2902.2 \mathrm{~m}^{3} / \mathrm{d}\right.$ in Zawadka catchement and $4940.3 \mathrm{~m}^{3} / \mathrm{d}$ in Ostra catchement) and admissible volume of groundwater evaluation $\left(1802.2 \mathrm{~m}^{3} / \mathrm{d}\right.$ in Zawadka catchement and $4191.9 \mathrm{~m}^{3} / \mathrm{d}$ in Ostra catchement) (Dendys \& Korzec 2014, Mars 2014). Finally, quantitative status of Ostra and Zawadka catchment was classified as good. The results of chemical analysis were compared with the Ministry of Health Regulation about health suitability of water for human consumption. The value of nitrates was up over $100 \mathrm{mg} / \mathrm{L}$ (at the permitted $50 \mathrm{mg} / \mathrm{L}$ ) at Ostra catchenment. Additionally, water cannot be collected, due to exceeded value of the bacterial content of Coliform Group Bacteria and Escherichia coli at Zawadka and Ostra catchement. In summary water is not suitable for drinking (compared with Ministry of Health Regulation - Rozporzadzenie... 2010).

Research partially supported by status research No. 11.11.140.026 KHiGI AGH UST.

\section{REFERENCES}

Bajkiewicz-Grabowska E. \& Magnuszewski A., 2002. Przewodnik do ćwiczeń z hydrologii ogólnej [3 ${ }^{\text {rd }}$ ed.]. Wydawnictwo Naukowe PWN, Warszawa.

Dendys M. \& Korzec K., 2014. Ocena stanu ilościowego wód podziemnych małych zlewni na przykładzie zlewni potoku Zawadka w gminie Dębica. Technika Poszukiwań Geologicznych. Geotermia, Zrównoważony Rozwój, 1, 63-69. 
Korzec K. \& Dendys M., 2014. Ocena stanu chemicznego wód podziemnych w zlewni potoku Zawadka. Technika Poszukiwań Geologicznych. Geotermia, Zrównoważony Rozwój, 2, 41-49.

Mars M., 2014. Ocena stanu ilościowego wód podziemnych zlewni potoku Ostra. Akademia Górniczo-Hutnicza, Kraków [M.Sc. thesis]

Nescieruk P., Paul Z., Ryłko W. Szymanowska F., Wójcik A. \& Żytko K., 1992. Mapa Geologiczna Polski 1:200 000, plansza B, arkusz Jasło. Państwowy Instytut Geologiczny, Warszawa.

Rozporzadzenie Ministra Zdrowia z dnia 20 kwietnia 2010 r. w sprawie jakości wody przeznaczonej do spożycia przez ludzi. Dz. U. 2010 nr 72, poz. 466.

Stefańska A., 2014. Ocena stanu jakościowego wód podziemnych zlewni potoku Ostra. Akademia Górniczo-Hutnicza, Kraków [M.Sc. thesis]. 